\title{
災害時支援透析における入院用クリニカルパスの作成と運用
}

\author{
村田 弥栄子 ${ }^{1}$ 山本多恵 ${ }^{1}$ 大場 郁 ${ }^{2}$ 中 道 崇 ${ }^{2}$ \\ 中山 恵 輔 ${ }^{2}$ 太田 一 成 ${ }^{2}$ 宮澤 恵実子 ${ }^{2}$ 清 元 秀 泰 ${ }^{2}$ \\ 上野誠司 ${ }^{3}$ 大友浩志 ${ }^{3}$ 佐藤 博 伊藤貞嘉 ${ }^{1,2}$ \\ 宮崎 真理子 ${ }^{1,2}$ \\ 東北大学病院血液浄化療法部 ${ }^{1}$ 同腎高血圧内分泌科 ${ }^{2}$ 気仙沼市立病院泌尿器科 ${ }^{3}$
}

キーワード : 支援透析, クリニカルパス, 災害

〈要旨〉

2011 年 3 月 11 日に発生した東日本大震災では, 宮城県の広い範囲, 特に東部沿岸地域は津波による市街地の流 失, 電気, 上水の供給停止, 通信の途絶など, 大きな被害を受け, 災害拠点病院への救急患者集中, 通院手段の確 保困難, 生活環境の悪化が生じ, 被災地外での支援透析を要した. 災害支援透析において, 被害が大きい依頼側に, 通常の臨時透析と同レベルの情報提供を求めることは, 災害支援の基本概念に沿わない. また, 支援側は, 業務増 大の中で初診の多数の透析患者の診療を行わなければならないが, 過酷な環境から避難してきた透析患者への対応 は，平時とは異なる視点が必要となる. そこで，われわれは震災後に多人数の入院支援透析を行うにあたり，災害 時透析入院クリニカルパスを作成し使用した. クリニカルパスの運用によって, 避難患者の容態把握を共通化, 標 準化することが可能で, 二次避難先への引継ぎにも利用した. 過去に例をみない大災害であったが, このクリニカ ルパスの活用は災害時入院支援透析における診療に有用であったので, ここに報告する.

\section{Effectiveness of a clinical pathway for dialysis patients affected by the Great East Japan Earthquake}

Yaeko Murata', Tae Yamamoto', Ikuko Oba ${ }^{2}$, Takashi Nakamichi', Keisuke Nakayama², Kazushige $\mathrm{Ota}^{2}$, Emiko Miyazawa ${ }^{2}$, Hideyasu Kiyomoto ${ }^{2}$, Seiji Ueno ${ }^{3}$, Hiroshi Otomo ${ }^{3}$, Hiroshi Sato ${ }^{2}$, Sadayoshi Ito $^{1,2}$ and Mariko Miyazaki ${ }^{1,2}$

Department of Blood Purification ${ }^{1}$, Division of Nephrology, Endocrinology, and Vascular Medicine, Department of Internal Medicine ${ }^{2}$, Tohoku University Hospital; Department of Urology, Kesennuma City Hospital ${ }^{3}$

Key words : dialysis, clinical pathway, disaster

〈Abstract〉

The Great East Japan Earthquake (March 11, 2011), which caused unprecedented damage, also greatly affected dialysis facilities in Miyagi Prefecture. In particular, the coastal areas were devastated, affecting numerous chronic dialysis patients. The Supply of electricity and water was unstable, and communication links were paralyzed. The living conditions of the people were miserable. We requested dialysis facilities outside the disaster areas to provide treatment for chronic dialysis patients, because the quality of dialysis could not be maintained under the conditions. In regard to dialysis treatment, requesting the afflicted dialysis facilities to provide usual medical information about chronic dialysis patients does not fit into the basic philosophy of disaster relief. On the other hand, we had to treat many chronic dialysis patients who were admitted to our hospital for the first time. Issues related to the medical treatment of patients who were evacuated from the disaster-afflicted areas were quite different from those in ordinary situations. Therefore, we formulated a "clinical pathway for the hospitalization of chronic dialysis patients" as a tool to visualize information and allow it to be shared among different professionals and institutions. The clinical pathway allowed the standardization and understanding of patients' conditions during

村田＼cjkstart弥栄子 東北大学病院血液浄化療法部％ 980-8574 宮城県仙台市青葉区星陵町 1-1

Yaeko Murata Tel : 022-717-7393 Fax : 022-717-7486

〔受付日：2011 年 11 月 28 日, 受理日：2012 年 2 月 9 日〕 
hospitalization and was also helpful for the handover of patients to dialysis facilities in Hokkaido. The findings suggested that the clinical pathway would be a useful tool for chronic dialysis patients. We report the details in this article.

\section{緒言}

2011 年 3 月 11 日に発生した M9 の巨大地震では広 い範囲で大津波が発生し, 死者 1 万 5,839 名, 行方不 明 3,642 名（11月 17 日現在）を出した。耐震や免震 建築の進歩と, 多くの施設では設備や機器の損傷を防 ぐ対策が行われていたことにより, 設備, 機器は無事 であったが, 浸水による使用不能や，長期間にわたる， 広い範囲での上水道や商用電源の停止を被った，幸 い，われわれの施設は，巨大地震翌日から血液浄化療 法が通常通り可能であった。しかし，宮城県の沿岸北 部は，1 透析施設が津波により流失, 災害拠点病院の 機能は維持されていたが，一般の被災傷病者と透析患 者が集中する事態となった。この地域は医療環境以外 にも, 通院困難, 生活環境悪化, 病院周辺で断続的な 火災の発生などのため, 被災地外での, 支援透析を要 した．宮城県の南北に接する福島県と岩手県ではそれ ぞれの県の被害が大きく，西に接する山形県では，す でに多くの避難患者の支援透析を受け入れていた。 そ こで, 最も震災の影響の少ない地域である北海道に支 援透析を依頼する方針とした，移動に際しては，災害 医療コーデイネータの調整により，一次避難先として われわれの施設で， 3 ないし 4 泊の入院加療を行った 後, 二次避難先である北海道に向けて出発することと なった。広域避難に際し，搬送時の最終準備として患 者のメディカルチェックを行う場所，機関として Staging Care Unit (SCU) という概念がある ${ }^{1)}$. 今回 われわれが担ったのは，その SCUとしての役割で あったといえる，患者の病状やわれわれの体制も，災 害時には，通常の臨時透析とは異なるため, 受け入れ に際し，これらの視点や体制を盛りこみ，かつ避難患 者の容態把握を共通化，標準化する災害時支援透析に 特化したツールが，必要と考えられた。しかし，過去 に類をみない災害規模や被災の質であり, 即座に参考, 利用できるものはなかった。そこで，独自に災害時透 析入院クリニカルパスを，受け入れまでの数日間で作 成し運用した。

\section{I . 目 的}

入院受け入れに際しては, 患者は当院 15 箇所の病
棟に分散して受け入れること, 過去に経験のない被災 直後の患者の診療を行うことから, 容態把握を共通化, 標準化し, 一次対応から専門的知識を要する三次対応 までスムーズに連携できることを目的として，クリニ カルパスを作成した.

\section{II. 対象と方法}

\section{1. 対 象}

発災日を Day 0 と起算し, Day 5 から 7 にかけて, 送り出し側（被災側）では，移動患者の決定が行われ， Day 8 に陸路 3 時間の道程で, 被災地から当院に移動 した.この維持透析患者 78 名の入院に対し, 作成し たクリニカルパスを運用した。

\section{2. 災害時透析入院クリニカルパス}

作成した災害時透析入院クリニカルパスを図 1 に示 す．項目は，通常のバイタルサインの記録や異常時対 応が基本となっているが, 何らかの併発症治療が必要 な状態をスクリーニングし，腎臓や透析専門医へのコ ンサルトの目安, 災害後に特化した重要事項を一覧で きることが，このクリニカルパスの特徴である。具体 的には, チェック項目に酸素飽和度を入れ, 呼吸器感 染や心不全の発見に努めた。 また, 発熱時の予測指示 には，インフルエンザの迅速検査をルーチンとした． これは災害後, 全般的な肺炎の増加, 一部の避難所で インフルエンザの発生が報告されていたためである. 栄養管理では，災害後で食事量や内容に配慮が困難な 状態の中，インスリン使用者は，その必要量が不安定 となるため，平素インスリンを使用していた患者に限 り, 血糖を 1 日 3 回測定し, $80 \mathrm{mg} / \mathrm{dL}$ 以下, $300 \mathrm{mg} /$ $\mathrm{dL}$ 以上の場合に糖尿病専門医の指示を仰ぐこととし た.

\section{3. 災害時支援透析臨床情報集約シート}

一次移動に際し，受け入れ側のわれわれは，資料が なくとも対応可能な体制を考慮し，災害時支援透析臨 床情報集約シートを作成した（図 2)。臨床情報集約 シートは, 当院から現地に迎えに行く同乗医師, 看護 師が持参し, 移動の車中で收集可能な基本情報をまと め,トリアージを行った者がバイタルサインを記入し た，最優先項目は，災害前に治療を受けていた医療機 関, 曜日, 体重, 最終透析日, ADLについてである。 透析年数, 原疾患, 既往歴, 禁忌薬, アレルギー, イ 


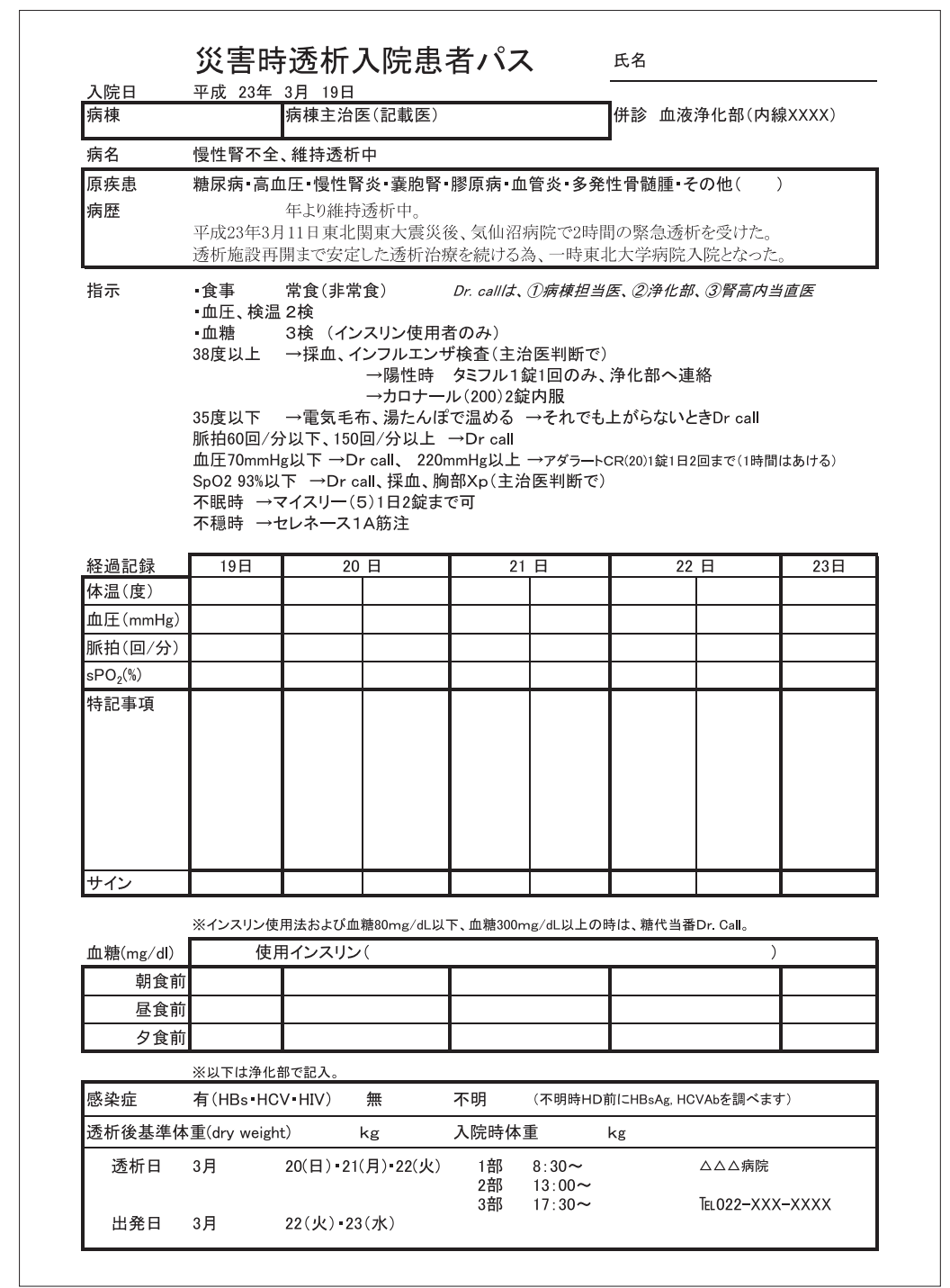

図 1 災害時透析入院クリニカルパス

患者の容態把握を共通化, 標準化するためクリニカルパスを作成した，通常 のバイタルサインの記録と異常時対応を基本とし, 何らかの併発症治療が必 要な状態をスクリーニング, 専門医コンサルトの目安, 災害に特化した重要事 項を一覧できることが特徵である。

ンスリン使用歴，家族の連絡先の項目を 1 枚にまとめ た.

\section{III. 結果}

\section{1. 災害時透析入院クリニカルパスの運用と追加事項}

今回の高血圧対策は, 追加投薬基準を緩く設定した. 不眠，不穏には定型的な対応を盛り込んでいるが，こ の点については, 後述の通り, さらに追加対応が実施 された。 また，病棟での検査は異常が認められた時と したが,一方で透析開始時に血液浄化療法部の指示で, 対象患者全体に血液検査を実施した. クリニカルパス への採血予定項目の記載は省略している. 検査結果を
透析専門医がチェックし，異常時の対応を行った。さ らに, Day 2 以降，随時受け入れていた被災者の透析 実施を行ううちに，今回クリニカルパスに盛り込んで いない事項にも，配慮が必要なことがわかってきた。 そこで, 78 名の入院受け入れ (Day 8) に際しては, 感 染管理室による発熱を伴う感染症スクリーニング回 診, 皮膚科による伝染性皮膚疾患スクリーニング回診, リエゾンナースによる急性ストレス反応のスクリーニ ング，医療ソーシャルワーカーの病室訪問などを行っ た.

透析予定は，受け入れ時に血液浄化療法部でベッド 割付を行い，時間帯を記入して病棟に伝達した。最終 終了時間は 23 時を原則とし, 深夜は休息がとれるよ 


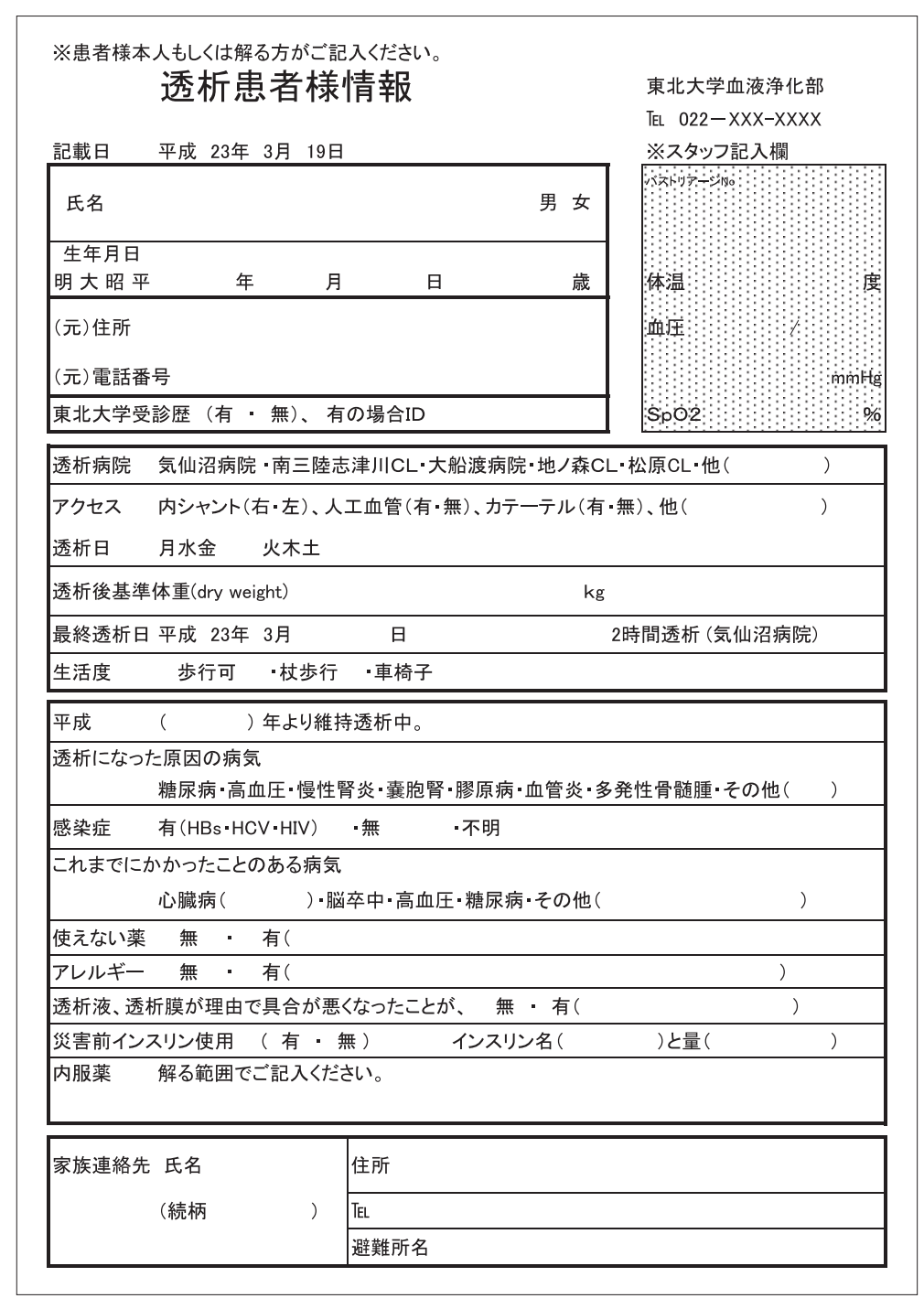

図 2 災害時支援透析臨床情報集約シート

この用紙のみで臨床情報の集約が可能となることを目標に作成した。収集 可能な基本情報をまとめ, 移動中の車内でトリアージを行った者が, バイ タルサインを記入した。

うにしたところ，透析のベッドがどうしても不足し， 10 名の患者は徒歩 5 分の距離にある施設で透析を 行っていただいた.Day 9 から 11 にかけて 1 回の血 液透析を行った後に，空路北海道札幌市および近郊に 77 名が移動，1名が仙台市近郊に移動した。このパス 表は転出時に複写して転院先に引き継いだ。

\section{2. 災害時支援透析臨床情報集約シート}

今回は，基本情報，発災前の透析条件と処方控，透 析経過記録の 4 種の帳票を送り出し側で準備可能で あった。この準備された詳細な情報により，診療を 行ったが，われわれは臨床情報集約シートのみでも診 療可能なことを目標に作成，記入した。

\section{IV. 考 察}

透析医療は，施設設備やインフラに大きく依存し， 1978 年 6 月 M7.4 の宮城県沖地震以来, 災害時に脆弱 であることは広く知られている，そこで，この構造的 課題をカバーするべく， 30 年以上にわたり，対策をた て, 改善に取り組まれてきた分野でもある。建築工学 は時代とともに進歩しているが, 大地震はその後も各 地で発生し, 地震の摇れ方の特徵, 地域の特性により 多様な被害が起こっている。，その都度，透析施設，設 備や機器に対する地震対策, 災害ネットワーク構築が なされてきた. 一方, 透析患者側の災害脆弱性や要援 護度は，時代とともに高まっている，年々，患者の高 
齢化，核家族化が進行し，腎不全に加えて糖尿病，心 血管系合併症などの複合病態を有する患者が増加して いる。したがって，被災地では，過去の報告や対策は 役には立つが，それだけではカバーしきれない新しい 課題に直面し，しかも速やかに対応する必要が生じる.

大災害後の医療は, 機能の制約や, 周辺医療機関の 被災のため，傷病者が集中するなど，災害拠点病院で あっても，資源や情報が限定的な中で，優先度を考慮 し，かつ一定の質を担保した医療を提供しなければな らない，われわれの施設は，高度先進医療や災害時医 療拠点の機能を有しており, 本震直後は, 地震の摇れ による建物の倒壊や落下物による多数の傷病者を受け 入れるべく準備をしたが，当院には重症外傷者の搬送 もごく少なく, 外傷後の急性血液浄化の要請はなかっ た。翌日以降, 沿岸の津波被災地域の最前線で医療に 奔走する災害拠点病院に対し, 積極的な後方支援, 患 者受け入れが可能となった，後方支援活動からは，最 前線の医療ニーズ, 本震災時の傷病の特性, 避難所環 境の情報, 特に感染症やサイコロジカルファーストエ イドなどの周辺分野の情報も多く集まることとなっ た.

今回われわれが使用した災害時透析入院クリニカル パスは, 大人数の入院受け入れ決定から, クリニカル パスを使うことを決め, さらに並行して随時受け入れ ていた避難者への支援透析でみられた課題を参考に, 数日間で作成したものであったが, 入院後の病棟診療 には有効で，当初の目的は達することができた．

しかし，実際に使用してみると，支援側としてある いは被災側として副次的な部分にいくつか追加変更を 考慮すべき点もあり，特に予測指示の部分について以 下に考察する.

血圧の管理は，持参薬がある場合，カルテの別ペー ジにリストアップしていたが, 平時に服用している薬 剤を持参していないことも想定した，そこで，極端に 高い場合に降圧剤を頓服する指示としたが，震災後に は, 血圧上昇がみられ, 心血管イベント発生のトリガー となる危険もあり ${ }^{2)}$, さらに低い值での頓用基準でも よかったかもしれない，不眠は災害後の急性ストレス の中で多くみられる3 が, 睡眠導入薬よりも患者の話 を傾聴するなどの対応が可能であれば，より推奨され る対策であるともいわれる ${ }^{4)}$. 今回は，入院日にリエ ゾンナースが病室訪問を行い, 緊急対応を必要とする 急性ストレス反応の兆候を示す患者がいないことを確 認した．最初は，一般的な睡眠導入剤による不眠対策 を頓用で行い，無効の場合に専門科に改めてコンサル トする方針とした，急性ストレス反応の中でも重く,
危険な兆候を，誰にでも判断できる項目としてクリニ カルパスへ追加することについては, 今後, 専門領域 での検討を要すると思われる. 避難所での集団生活, 水道や電気のない自宅で生活を扔くっていた避難患者 に対して，当初観察項目には入れていなかったが，伝 染力の強い皮膚感染症や軽い外傷からの足病変の悪化 にも注意して抄きたいと考え，急遽皮膚科に回診を依 頼した。この点は比較的わかりやすい項目でもあり， 観察項目に加えてもよいかもしれない.

当院も被災地にあり, 薬剤の入荷状況, 検査部門, 厨房など病院の機能が一部限定され，全く被害のない 地域での支援透析と同じ体制とはいえなかった。しか し，家族，住居や職場を失うなど人的物的な直接被害 をうけた場合はもちろん，これらの直接的被害を受け ていない場合であっても，甚大な被害が地域全体に及 んでおり, 地域住民が急性ストレスに暴露しているこ とを共感できる点では, 被災地ならではの被災者支援 ができた部分もあった。

\section{まとめ}

東日本大震災による被害は，広範囲にわたり，人的 物的被害は言うまでもなく, 自治体, 公共事業, 地域 の基幹産業や医療など数值では示しきれない性質のも のである都市機能そのものの被災があった．透析医療 における災害対策の中で広域避難を行う判断や方法に ついては，過去に経験がほとんどなく，今後も継続的 に検証をしていかなければならない，今回われわれが 行った広域避難に扔ける中継, 一時避難先としての役 割も，全く未経験の中で取り組んだが，結果的には広 域避難を安全に進めるために有効であった。災害時医 療では，すべての医療従事者に総合診療科の役割が求 められるが, 透析医療に特殊性があることは否めない. クリニカルパスのような標準化ツールは, 他分野の医 療従事者にも，不安なく一定の診療ができるものとし て有用であった，ただし，その前提として，大きな被 害の中で, 支援依頼側の最大の努力による情報整理と, また二次避難先である北海道の透析医療関係者による 緻密な準備があったことを, 最後に改めて強調してお きたい.

\section{文献}

1）山内 聡, 小林道生, 阿部喜子, 後藤えり子, 佐藤 大, 野村亮介, 篠澤洋太郎：Preparation for medical transportation to be provided for the Miyagiken-oki Earthquake: Can we establish a Staging Care Unit 
(SCU), and can wide-area medical transportation be realized with the use of Self Defense Force aircraft? 日本集団災害医学会誌 $15 ： 165-170,2010$

2）茠尾七臣 :【災害と心疾患】大災害時の心血管イベント 発生のメカニズムとそのリスク管理 自治医科大学 2004 年提言より。心臟 $39: 110-119,2007$

3）辻内环也, 吉野一浩, 嶋田洋徳, 伊藤克人, 赤林 朗, 熊野宏昭, 野村 忍, 久保木富房, 坂野雄二, 末松弘 行: 阪神・淡路大震災における心身医学的諸問題 (II) 一
身体ストレス反応を中心として，心身医 36：658-665, 1996

4）アメリカ国立子供トラウマティックストレス・ネット ワーク アメリカ国立 PTSD センター: 災害時のここ ろのケア サイコロジカル・ファーストエイド 実施 の手引き。111-112, 医学書院, 東京, 2011 